\title{
초청리뷰논문
}

\section{A review of therapeutic exercise strategies for prostate cancer and benign prostate hyperplasia}

\author{
Jin Hwan Yoon* \\ Hannam University
}

\begin{abstract}
[Purpose] Prostate problems, such as prostate cancer, and benign prostate hyperplasia have been recognized as problems largely related to androgens and genetic factors. They affect a large fraction of the elderly population, contributing significantly to morbidity and mortality. Therefore, the purpose of this review paper was to investigate a therapeutic strategies for prostate cancer and benign prostate hyperplasia. [Methods] In order to determine the therapeutic exercise strategies for prostate cancer and benign prostate hyperplasia, previous literature was reviewed with MEDLINE, PubMed, and Scopus databases. [Results] Prostate cancer and its associated treatments can cause significant and lasting morbidities, such as cardiovascular and sexual dysfunctions. Various interventions have attempted to prevent or mitigate these dysfunctions. This review summarizes the available evidence concerning the effects of exercise training on male sexual health in the cancer prevalent population. Smoking cessation, regular exercise, and maintaining healthy weight are important public health targets for intervention. Importantly, several lifestyle modifications may lower the risk of developing more aggressive cancer or offer survival benefits to prostate cancer patients. [Conclusions] In this review article, physical exercise training can increase apoptosis markers in the prostate, suggesting exercise training as a potential novel therapeutic strategies for treating prostate cancer and benign prostate hyperplasia. Future studies in more advanced and varied prostate cancer populations are required to ascertain the duration, intensity and frequency of exercise that optimizes the effects of exercise training on prostate cancer and benign prostate hyperplasia.
\end{abstract}

Key Words: Prostate cancer, Benign prostate hyperplasia, Exercise, Prostate problems

\section{서 론}

전립선암(prostate cancer, $\mathrm{PCa}$ )은 전 세계적으로 주 요 공중 보건의 및 의학적 중요성이 커지는 질병이며, 선 진국에서 전립선암은 남성에게 가장 흔한 비 피부암으로 써, 암 관련 사망의 주요 원인 중 하나로 보고되고 있다

논문 투고일 : 2020. 02. 24.

논문 수정일 : 2020. 03. 09

게재 확정일 : 2020. 03. 10.

* 교신저자 : 윤진환(yoonjh@hannam.ac.kr).
(Campos et al., 2018). 그러나 전립선암의 병인은 아직 까지 알려지지 않고 있다(Wolk, 2005). 최근 우리나라 도 고령화에 따라 암에 대한 위험이 증가하고 있는데, 특 히 남성 노인에게 있어 전립선암은 흔하게 발생되고 있으 며, 점차 서구화되는 생활습관이나 식생활 문화의 변화는 우리나라 전립선암 발생률을 증가시키고 있다.

2016년도 암 등록 통계(Korean National Cancer Center, 2018)에 따르면, 2016년에 우리나라에서 새로 암이 발생한 암환자 수는 22만 9180명이다. 이중 남성은 12 만 68 명, 여성은 10 만 9112 명으로 예년과 비슷한 차 
이로 남성이 여성보다 약 1 만명 정도 많았다. 암 발생 변 화를 살펴보면, 간암은 줄었지만 성별에 따른 전립선암과 유방암 발생이 눈에 띄게 증가했다. 우리나라에서 발생한 주요 암 종류 순위와 발생율은 1 위 위암(13.3\%), 2위 대 장암 $(12.3 \%), \quad 3$ 위 갑상선암 $(11.4 \%), \quad 4$ 위 폐암 (11.2\%), 5위 유방암(9.5\%), 6위 간암(6.9\%), 7위 전 립선암 $(5.1 \%), 8$ 위 담낭암 및 기타 담도암 $(2.9 \%), 9$ 위 췌장암 $(2.9 \%), 10$ 위 신장암 $(2.2 \%)$ 이다. 전립선암 발생 자 수는 2016년 1만1800명으로 2015년 1만 304명 보다 1496명(14.5\%)이 증가했다. 남성의 경우, 전립 선암은 간암을 제치고 4 번째로 많이 발생했다.

전이성 전립선암 환자 10 명 중 9 명은 뼈 전이를 경험 하는 것으로 보고하고 있지만 왜 유독 전립선암에서 뼈 전이가 자주 발생하는지 아직 명확한 원인이 밝혀지진 않 았다(Saad et al., 2018).

다만, 이와 같은 암과 뼈 전이 발생과의 상관관계는 약 100여 년 전 발표된 '종자와 토양(The Seed and Soil Hypothesis)' 가설이 가장 신빙성이 있는 것으로 알려져 있다. Choi et al. (2008)은 농부가 씨앗을 뿌렸을 때 비 옥한 토양에서만 싹이 나고 열매를 맺는 것처럼, 암세포 (seed)가 자리 잡고 성장하기에 적합한 특정 신체 조직 (soil)이 있는데, 그 중 전립선암 세포는 '빼'라는 토양과 궁합이 좋다. 처음 전립선에서 탄생한 종자(암세포)는 혈 액이나 림프액을 타고 돌아다니다가 성장하기에 좋은 환 경인 빼에 머물러 전이를 일으킨다. 전립선과 가까운 척 추나 골반 등에 뼈 전이가 특히 빈번히 발생한다. 이는 전 립선에서 대정맥으로 이어지는 정맥 순환이 척추나 골반 을 지나기 때문으로 추정된다고 하였다.

지난 수십 년 동안 운동의 이점에 대한 이해가 높아짐 에 따라 연구자들은 운동 요법의 가능성에 관심을 가지게 되었다. 각 운동에는 운동 훈련 중에 발생하는 고유한 특 성과 생리적 기전이 있기 때문에 운동의 효과와 근본 메 커니즘은 아직 명확하지는 않다.

최근 우리나라도 전립선암과 전립선 비대증이 급속히 증가하고 있는 실정으로 의료비 부담 증가뿐만 아니라 남 성 건강에 중요한 문제로 대두되고 있다. 따라서 본 연구 에서는 운동이 전립선암과 전립선 비대증에 어떠한 영향 을 미치는가를 문헌 고찰하고자 한다.

\section{본 론}

\section{각종 암 발생 위험성에 대한 운동 효과}

신체 활동, 좌식 행동(sedentary behaviour) 및 식이 요법 등의 다양한 생활양식 요소는 암과의 관련성이 있어 많은 연구들이 진행되고 있다. 많은 연구들에서 규칙적인 신체 운동은 각종 암 위험을 줄이는 것으로 잘 알려져 있 다. Mishra et al. (2012)은 4,800 명의 피험자를 대상으 로 Cochrane 데이터베이스의 체계적인 분석을 한 결과 암 치료 중 가벼운 운동, 중간 강도 또는 격렬한 운동과 비교할 때 중간강도 이상의 운동이 건강 관련 삶의 질, 신 체 기능, 불안, 피로 및 수면 장애가 크게 개선되었다고 보고하였다. 또한 전 세계에서 실시 된 73개 연구의 역학 적 데이터(Lynch, Neilson, \& Friedenreich, 2011)에 따르면 비활동적인 여성에 비해 신체적 활동성이 많은 여 성에서 유방암 위험이 $25 \%$ 감소한다고 보고하고 있다. 또한 Scott et al.(2020) 은 투약 일정과 무관하게 16주 간 유산소 운동 훈련은 이전에 유방암으로 치료받은 환자 의 심폐기능이 유의하게 개선되었다고 보고하였으며, Travier et al.(2015)도 초기 유방암 환자를 대상으로 18 주 동안 유산소 운동과 근력 운동을 시킨 결과 피로, 심폐 기능, 근력이 유의하게 증가하였다고 보고하였다. 메타 분석 연구에서도 신장 암과 신체 활동의 역 상관관 계를 나타내어 운동이 신장암의 위험성을 낮추는 것으로 보고하였으며(Behrens \& Leitzmann, 2013), Brown et al.(2018)은 대장암 1기 및 3기 환자에서 6개월간 유 산소 운동을 시킨 결과 건강지수, 수면의 질, 삶의 질이 유의하게 향상하는 것으로 보고하였다, Kim et al. (2019)은 우리나라 성인 257,854명을 대상으로 한 코호트 연구에서 땀을 유발 할 수 있는 중간 수준의 운동 은 심근 경색, 뇌졸중, 고혈압, 2 형 당뇨병, 위암, 폐암, 간암 및 두경부 암의 위험율이 가장 낮았다고 보고하였다.

마찬가지로 폐암, 결장암, 전립선암 등 다른 많은 암의 위험을 줄이는데 있어 여러 연구들에서 운동이 암 발생에 보호 역할을 하는 것으로 밝혀졌다(Boyle et al., 2012; Sun et al., 2012; Voskuil et al., 2007; Liu et al., 2011). 


\section{전립선암 발생의 병인}

전립선은 (그림 1)과 같이 남성에게만 있는 생식기관 이다. 방광 아래에 위치해 소변이 배출되는 요도를 감싸 고 있는데, 배뇨와 생식기능에 관여한다. 무게는 $15 \sim 20 \mathrm{~g}$, 길이는 $4 \mathrm{~cm}$, 폭은 $2 \mathrm{~cm}$ 정도로 호두만한 크기 다. 2 차 성장기부터 20 대 후반까지 매년 $1.6 \mathrm{~g}$ 씩 급속 성 장하여 성인 크기를 이루며 30 대 이후부터는 매년 $0.4 \mathrm{~g}$ 씩 커진다.

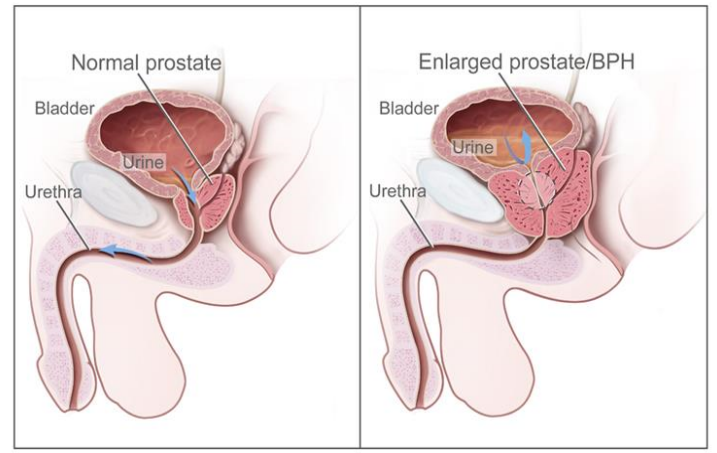

Fig. 1. prostate structure \& prostate hyperplasia

이와 더불어 60 대에는 전립선 조직의 결절성 과증식 및 비대가 동반되어 하부요로폐쇄 증상을 유발하게 된다. 전립선에서 분비되는 액은 정자의 영양분이 되고 요도의 감염을 막는 역할을 한다(Kim, 2007).

인간 및 마우스 전립선은 세포적 유사성뿐만 아니라 해부학적 차이를 나타낸다. 마우스의 배측 전립선 (dorsolateral prostate)은 인간 전립선의 말초 영역과 동일하고(Berquin et al. 2005), 인간 전립선암의 약 60 $\%-75 \%$ 가 발생한다(Haffner et al., 2009). 전립선암 의 원인은 아직까지 분명하게 밝혀진 것은 없으나 생활양 식, 노화, 만성적 흡연, 만성적 알콜 섭취, 비만, 신체활 동 부족, 가족력, 세균 감염 등 다양한 원인 등이 전립선 암 위험 증가와 관련이 있는 것으로 보고되고 있다 (Littlejohns et al., 2016; Pernar, Ebot, Wilson, \& Mucci, 2018). 비만은 인슐린 축의 탈 조절(deregulation), 성 호르몬 분비, 아디포카인 신호 전달 및 산화 스트레스 를 포함하는 다양한 생물학적 메커니즘을 통해 전립선암
의 발병에 관여하는 것으로 제안되었다. 비대성 주변 주 위 지방 세포는 종양 세포의 화학-유인을 통해 전립선암 의 국소 확산을 촉진 할 수 있다(Bandini, Gandaglia, $\&$ Briganti, 2017). 이러한 이유로 비만 환자는 전립선암 발생이 높다고 보고하였다(Dickerman \& Mucci, 2020).

\section{전립선암 치료와 예방을 위한 운동 전략}

운동은 암 위험에 영향을 미치는 것으로 밝혀진 환경 요인 중 하나로 체계적인 메타 분석은 총 신체 활동이 전 립선 암 발병 위험 감소와 관련이 있다고 보고되고 있으 며, 역학 연구에서도 전립선암 진단 후 운동은 전립선 암 개선과 치료중인 환자들에서 긍정적인 결과를 보고하였 다(Baguley et al., 2017; Bourke et al., 2016). 인간 을 대상으로 한 연구들에서, 중간 강도의 저항 운동은 암 관련 피로와 삶의 질을 향상시키는 것으로 보고되고 있고 (Baguley et al., 2017), 미국(Patel et al., 2005)과 유 럽(Johnsen et al., 2009; Nilsen, Romundstad, \& Vatten, 2006)의 3 가지 대규모 코호트 연구에서 신체 활동이 전립선암의 위험으로부터 상당히 보호되는 것으 로 보고하였다.

많은 코호트 연구들에서 신체 활동과 진행성 및 치명 적인 전립선암의 위험 사이에 적당한 역의 연관성을 보여 주었는데, HPFS 코호트 연구에서 미국인 65 세 이상의 남성 47,620 명을 대상으로 가장 활발한 신체활동을 하고 있는 남성은 진행된 전립선암 위험이 $77 \%$ 낮았다고 보 고하여(Giovannucci et al., 2005), 신체 활동의 수준이 증가하는 것은 전립선 암 위험의 점진적인 감소와 관련이 있다는 것을 보여주고 있다. CPS-II 코호트 연구에서도, 미국 남성 72,174 명을 대상으로 레크리에이션 신체 활동 이 가장 높은 남성은 레크리에이션 신체 활동에 참여하지 않은 남성에 비해 전립선암 위험이 $31 \%$ 낮다고 보고하 였다(Patel et al., 2005).

Nilsen et al.(2006)도 29,110명의 노르웨이 남성을 대상으로 한 코호트 연구에서 레크리에이션 신체 운동이 진행된 전립선암 및 전립선암 사망의 위험 감소와 밀접한 관련이 있다고 보고하였다.

이와는 대조적으로, 유럽 영양 및 암에 대한 코호트 연 구에서는 유럽국가 8 개국 총 127,923 명을 대상으로 직 
업 활동과 진행된 전립선 암 위험 사이에 역의 연관성을 보였지만 여가 활동과는 관련이 없었다는 연구결과도 있 다(Johnsen et al., 2009).

전립선암 진단을 받은 남성 중 신체 활동은 생존율 향 상 및 전립선암 진행 감소와 관련이 있다. 전립선암 환자 2,705 명을 대상으로 한 연구에 따르면 일주일에 3 시간 이상 활발하게 운동을 하는 사람은 주당 1 시간 미만의 활동에 비해 전립선 관련 사망률이 $61 \%$ 낮다고 보고하 였으며 (Kenfield et al., 2011), 일주일에 3 시간 미만의 쉬운 걷기와 비교하여 주당 최소 3 시간의 걷기에 종사하 는 남성이 재발 위험이 낮게 관찰됨을 보고하였다 (Richman et al., 2011). 신체 활동이 전립선 암 위험을 변화시키는 메커니즘은 아직 확실하지 않지만 성 호르몬 수치, 항염증 경로 또는 IGF-축의 변화를 통해 작용할 수 있을 것으로 보여 진다(Gann et al. 1996).

인간을 대상으로 한 임상연구에서 Martin et al. (2015)은 47-80세 전립선암 환자 87명을 10주간 운 동을 시킨 결과, 최대산소섭취량 $75 \%-80 \%$ 의 고강도 운 동이 60-65\% 의 저강도 운동과 비교하여 고강도 운동그 룹에서 심폐기능이 유의하게 향상되는 것으로 보고하였 다. 동물을 대상으로 한 연구에서 Esser er al.(2010)은 형질전환 마우스를 대상으로 10 주 동안 달리기를 수행한 결과 전립선암 진행을 감소시키는 것으로 보고하여 운동 이 전립선암 발병에 있어 효과적이라고 보고하였다. 최근 동물을 대상으로 한 연구에서 Dufresne et al.(2020)은 전립선암 모델 마우스를 대상으로 방사선 치료 중에 2주 간 트레드밀에서 속도 $18 \mathrm{~m} / \mathrm{min}$ 로 주 5 회 운동을 시킨 마우스는 종양세포에 대항하여 자연살해세포(natural killer cell) 활성의 향상에 의하여 전립선암 치료에 효과 적인 결과를 보고하였다.

\section{운동의 전립선암에 대한 보호기전}

신체 활동에 기인 할 수 있는 전립선암 보호 메커니즘 은 아직 명확하지 않지만 인슐린 순환 수준, 인슐린 유사 성장 인자(IGF) 및 안드로겐이 역할을 할 수 있다고 제안 되었다(Hsing et al., 2001; Chan et al., 1998; Gann et al., 1996). 신체 활동은 테스토스테론 순환 수준을 낮 춰 주며(Hackney, Sinning, \& Bruot, 1998), 성 호르
몬과 전립선암 위험 사이의 연관성이 일치하지 않지만, 일부 연구에 따르면 낮은 수준의 테스토스테론이 전립선 암 위험 감소와 관련이 있을 수 있음이 보고되었다 (Heikkila et al., 1999; Ngo et al., 2002). 인슐린은 테스토스테론의 생성과 대사를 조절하는 것으로 보이며, IGF-1은 전립선암 세포에서 증식을 자극하고 세포 사멸 (apoptosis)을 억제하여 전립선암의 증가와 관련이 있다 고 보고하였다(Li et al., 2003).

스웨덴의 코호트 연구에서 전립선암 환자 281명의 남 성을 대상으로 한 연구에서 전립선암 환자는 혈청 IGF-I 의 농도가 높았으며 (Stattin et al., 2004), IGF-축의 또 다른 부분인 IGF- 결합 단백질(IGFBPs)도 신체 활동에 의해 영향을 받는데, IGFBP-3는 인간의 전립선암에서 세포사멸을 자극하는 것으로 보고되고 있다(Hong et al., 2002).

\section{전립선 비대증의 개요}

전립선 비대증 (prostate hypertrophy; PH)은 악성인 암과 달리 양성이기 때문에 일반적으로 양성 전립선 비대 증 이라고 부른다(benign prostate hyperplasia; $\mathrm{BPH})$. 우리나라도 전립선 비대증 유병율이 10년간 약 3.3 배 증가한 것으로 조사 됐는데, Foundation for Korean Urological Association(2019)이 2008-2017년 건강보험심사평가원의 데이터를 활용해 분석한 결과 전 립선 비대 유병률은 2008년 7만 5204 명에서 2017년 25 만 265명으로 늘었다. 신규 전립선 비대증 환자도 매 년 늘어나고 잇는 추세를 보였다. 전립선 비대증은 50 대 남성에서는 $42 \%, 60$ 대에서는 $70 \%$ 이상, 70 대에서는 $90 \%$ 까지 유병률이 증가하는 질환으로, 노년기 남성에서 흔히 나타난다(Nickel, 2008). 전립선암은 전립선의 정 상세포가 암세포로 변하면 생기는데, 전립선 비대증과 전 립선암이 합쳐져서 증상이 더 악화될 수는 있지만 근본적 인 발병 원인이 다르기 때문에 전립선 비대증이 심해져 암으로 발전하지는 않는다. 전립선 비대증의 임상적 증상 은 방광 출구 폐색과 하부요로 증상 등으로 나타나는 복 합적 비뇨기계 질환이다(Roehrborn, 2008). 전립선 비 대증은 다양한 요소들에 의해 영향을 받는데 아직 그 기 전이 명확히 알려진 바가 없으나 노화에 따른 성호르몬의 
변화로 인한 전립선내 간질세포와 상피세포의 증식이 주 된 특징이다(McConnell, 1991).

\section{전립선 비대증의 병인}

전립선의 비대는 남성호르몬을 만드는 정상고환을 가지 고 있는 40대 이상의 남성에서 주로 발생하며 가장 중요한 원인은 testosterone 수치의 감소와 노화이다. Testosterone은 대부분 고환에서 생성되며 사춘기 전후로 남성 성기의 발달과 전립선의 발달 등 2 차 성장을 유도하고 뼈의 성장에도 관여하는데, 노년기가 되면 testosterone 수치가 상대적으로 낮아지지만 오히려 전립선 비대증은 더 많이 발생하게 된다. 남성호르몬은 testosterone과 dihydrotestosterone(DHT)의 두 가지 형태로 존재하는데, 전립선의 성장에 더 중요한 것은 DHT로 testosterone과 달리 나이가 들어도 양에는 큰 변화가 없다(Baisch, Otto, \& Fack, 1998; Kim, 2007).

양성 전립선 비대증 발병의 원인은 아직 명확하게 알 려져 있지 않지만 호르몬(androgen, estrogen)의 불균 형, 전립선의 간질(stromal)과 상피의(epithelial) 성장 인자들(growth factors)의 과잉 발현, 사이토카인과 스테 로이드 호르몬 등이 원인으로 알려져 있다(Roehborn \& McConneli, 2007). 그리고 나이, 가족력, 인종, 당뇨, 관 상동맥질환, 고혈압 등과 같은 만성질환, 흡연, 과도한 알 콜 섭취 등이 연관되어 있는 것으로 보고되어 있고, 또한 식생활 습관과 영양 요소는 다양한 기전을 통하여 양성 전립선 비대증에 영향을 미친다(Leedahl et al., 2013; Lee et al., 2019b; Schenk et al., 2010). Espinosa 2013)는 다불포화 지방 및 채소 섭취 등은 전립선 비대증 의 위험을 감소시킨다고 하였으며, 적당한 알콜 섭취는 전립선 비대증 위험을 감소시키는 것으로 보고되었다 (Parsons \& Im, 2009).

병리학적으로 양성 전립선 비대증은 상피와 간질 부분 의 세포 증식성(hyperplastic) 성장으로 인하여 전립선 에서 수많은 결절(nodules)이 생기는 것이 특징이다 $(\mathrm{Ho}$ $\&$ Habib, 2011). 나이가 들어 전립선의 증식을 유도하 는 다른 성장인자들을 지속적으로 자극하여 전립선비대 가 발생하게 된다. 전립선 비대증으로 수술받은 환자의 자손들이 같은 수술을 받을 확률이 그렇지 않은 사람들에
비하여 약 4.2 배 높은 것으로 보고되어 유전적 소인을 고 려할 수 있다(Kim, 2007; Pearson et al., 2003).

\section{운동의 전립선 비대증에 대한 보호기전}

신체활동과 운동은 건강상의 많은 이점을 보여주고 있 기 때문에 신체활동과 운동은 양성 전립선 비대증의 발병 및 진전에 대해 보호 기능의 역할을 할 수 있다. 운동과 전립선 비대에 관한 연구들에서 신체활동은 전립선 크기 감소, 교감 신경계 활성 감소(Platz et al., 1998; St Sauver et al., 2006), 전신 염증 수준 감소 등 몇 가지 메커니즘을 통해 전립선 비대증의 발달 및 진전에 대한 보호 기능의 역할을 하는 것으로 보고되었다(Abramson \& Vaccarino, 2002; Vesely et al., 2003). 노화와 함께 DHT의 과생산(overproduction)이 양성 전립선 비대증 발병의 원인이라고 하였다(Carson \& Rittmaster, 2003). 또한 양성 전립선 비대증의 원인을 cytokines와 같은 염증성 인자들의 증가와 염증에 의한 것이라는 보고 들이 있다(Chughtai et al., 2011; Lim, 2017).

\section{전립선 비대증의 치료와 예방을 위한 운동 전략}

규칙적인 신체활동은 양성 전립선 비대증 환자에 있어 서 전립선 비대증을 예방하고 비대증 발병율 위험을 낮춰 준다고 알려져 있다(Fowke et al., 2013). 국내의 코호 트 연구에서 Lee et al. (2014)은 양성 전립선 비대 증상 을 갖고 있는 40세 이상, 582명의 남성을 대상으로 신체 활동과 생활 양식의 설문지 조사를 실시하였다. 이 연구 에서 규칙적 운동, 운동 빈도, 좌식 시간, 레저 활동 시간 은 전립선 크기와 관련이 없었지만 좌식 시간만이 전립선 비대증의 위험도를 높여 주었다. 즉, 좌식 시간이 높은 환 자들 보다 좌식 시간이 낮은 환자들은 전립선 비대증의 위험이 유의하게 낮게 나타났다고 보고하였다. 또한, Lagiou et al. (2008)은 그리스 아테네에서 184명의 남 성의 직업에 따라 직무 신체활동을 평가했다. 이 연구에 서는 전립선 비대증 수술을 받은 환자들로 신체활동은 직 무 관련 신체활동 수준에 기초하여 낮은, 중간, 높은 수준 으로 분류하였다. 낮은 신체활동 수준과 비교하였을 때, 높은 신체활동 수준에서 전립선 비대증 위험의 감소가 관 
찰되었다. 그러나 Hong et al.(2006)은 전립선 비대증 환자를 대상으로 활동적인 그룹과 비활동적인 그룹 간의 차이가 없었지만 주당 운동 빈도로 분류했을 때 적당한 운동 빈도로 운동하는 그룹이 전립선 비대증의 위험을 오 히려 증가시켰다고 상반된 결과를 도출하고 있다. Wolin et al. (2015)은 28,404명의 전립선 비대증을 가진 환자 에서 규칙적인 운동을 하는 사람은 전립선 비대증을 개선 하는데 특히, 야간 빈뇨(nocturia)에 효과적인 전략이 될 수 있음을 시사하였다. 동물을 대상으로 한 연구들에서 $\mathrm{Ki}$ (2017)는 흰쥐를 대상으로 전립선 비대증을 유도한 후 트레드밀에서 $8 \mathrm{~m} / \mathrm{min}$ 로 3 주 동안, 주 5 일, 1 일 30 분 동 안 저강도 운동을 실시한 결과, 전립선의 무게가 유의하 게 감소되었으며, 전립선 지수도 개선되었다고 보고하였 다. 또한, Peng et al. (2013)은 전립선 비대증 유도 쥐를 대상으로 13 주간 $5-20 \mathrm{~m} / \mathrm{min}$ 로 주당 3 회, 30 분 점증적 부하 트레드밀 운동을 시킨 결과, 전립선 비대증을 개선 한다고 보고하였다. 이런 결과와 유사하게 Lee et al. (2019a)은 전립선 비대 유도 쥐를 대상으로 8주간 트 레드밀 운동을 시킨 결과, $\mathrm{DHT}$ 수준을 낮춰주고 염증인 자인 IL- $1 \beta$ 및 IL-6 농도를 감소시켜 양성 전립선 비대증 의 예방과 치료에 충분히 도움이 될 수 있을 것으로 보고 하였으며, $\operatorname{Lim}(2017)$ 은 양성 전립선 비대증은 대사증후 군과 염증이 주요 위험인자로써 식이와 더불어 규칙적인 운동이 전립선 비대증 위험을 줄일 수 있다고 하였다. 운 동과 양성 전립선 비대증은 역관계이며, 이 역관계의 효 과는 운동량에 따라 달라지며, 젊은 나이에 운동을 시작 하는 것이 효과가 크며, 이 효과는 양성 전립선 비대증의 치료 보다는 예방과 밀접한 관련이 있는 것으로 제시되었 다(Lee et al., 2019b).

\section{결 론}

운동 요법은 전립선암 및 양성 전립선 비대증 환자의 신체 기능을 개선하고 질병의 증상을 완화시키는 안전한 방법이다. 본 연구의 목적은 전립선암과 양성 전립선 비 대증을 위한 운동 치료적 전략을 도출하기 위하여 선행 연구들의 문헌을 고찰 한 결과 전립선암 및 전립선 비대 증 환자에 있어서 규칙적인 운동과 함께 금연, 적정체중
유지 등 몇몇 생활습관을 개선하면 전립선암 및 양성 전 립선 비대증의 위험을 감소시킬 수 있다는 것을 알 수 있 다. 본 연구 결과들로 보아 규칙적인 운동은 전립선암 세 포 사멸의 지표들을 증가시켜 운동이 전립선암 및 양성 전립선 비대증을 위한 잠재적인 치료전략으로 제시 할 수 있을 것이다. 미래의 연구들에서는 다양한 전립선암 및 전립선 비대증에 있어서 적정한 운동 기간, 운동 강도, 운 동 빈도를 고려한 연구들이 요구된다.

\section{참고문헌}

Abramson, J. L., \& Vaccarino, V. (2002). Relationship between physical activity and inflammation among apparently healthy middle-aged and older US adults. Archives of Internal Medicine, 162(11), 1286-1292.

Baguley, B. J., Bolam, K. A., Wright, O. R., \& Skinner, T. L. (2017). The effect of nutrition therapy and exercise on cancer-related fatigue and quality of life in men with prostate cancer: A systematic review. Nutrients, 9(9). pii: E1003. doi: 10.3390/ nu9091003.

Baisch, H., Otto, U., \& Fack, H. (1998). Growth of human prostate carcinomas with and without hormone alphadehydrotestosterone. European Urology, 34(6), 505-511.

Bandini, M., Gandaglia, G., \& Briganti, A. (2017). Obesity and prostate cancer. Current Opinion in Urology, 27(5), 415-421.

Behrens, G., \& Leitzmann, M. F. (2013). The association between physical activity and renal cancer: systematic review and meta-analysis. British Journal of Cancer, 108(4), 798-811.

Berquin, I. M., Min, Y., Wu, R., Wu, H., \& Chen, Y. Q. (2005). Expression signature of the mouse prostate. The Journal of Biological Chemistry, 280(43), 36442-36451.

Bourke, L., Smith, D., Steed, L., Hooper, R., Carter, A., Catto, J., Albertsen, P. C., Tombal, B., Payne, H. A., \& Rosario, D. J. (2016). Exercise for Men with Prostate Cancer: A Systematic Review and Meta-analysis. European Urology, 69(4), 693-703.

Boyle, T., Keegel, T., Bull, F., Heyworth, J., \& Fritschi, L. (2012). Physical activity and risks of proximal and distal colon cancers: a systematic review and meta-analysis. Journal of the National Cancer Institute, 104(20), 1548-1561.

Brown, J. C., Damjanov, N., Courneya, K. S., Troxel, A. B., Zemel, 
B. S., \& Rickels, M. R. (2018). A randomized dose-response trial of aerobic exercise and health-related quality of life in colon cancer survivors. Psychooncology, 27(4), 1221-1228.

Campos, C., Sotomayor, P., Jerez, D., González, J., Schmidt, C., Schmidt, K., Banzer, W., \& Godoy, A. S. (2018). Exercise and prostate cancer: From basic science to clinical applications. The Prostate, 78(9), 639-645.

Carson, C. 3rd., \& Rittmaster, R. (2003). The role of dihydrotestosterone in benign prostatic hyperplasia. Urology, 61(4 Suppl 1), 2-7.

Chan, J. M., Stampfer, M. J., Giovannucci, E., Gann, P. H., Ma, J., Wilkinson, P., Hennekens, C. H., \& Pollak, M. (1998). Plasma insulin like growth factor I and prostate cancer risk: A prospective study. Science, 279(5350), 563-566.

Choi, S. Y., Choi, W. H., \& Park, C. H. (2008). Treatment of bone metastasis in breast cancer. Korean Journal of Clinical Oncology, 4(1), 15-19.

Chughtai, B., Lee, R., Te, A., \& Kaplan, S. (2011). Role of inflammation in benign prostatic hyperplasia. Reviews Urology, 13(3), 147-150.

Dickerman, B. A., \& Mucci, L. A. (2020). Obesity, height, and advanced prostate cancer: extending current evidence toward precision prevention. Annals of Oncology, 31(1), 7-8.

Dufresne, S., Guéritat, J., Chiavassa, S., Noblet, C., Assi, M., Rioux-Leclercq, N., Rannou-Bekono, F., Lefeuvre-Orfila, L., Paris, F., Rébillard, A.. (2020). Exercise training improves radiotherapy efficiency in a murine model of prostate cancer. FASEB Journal, doi: 10.1096/fj.201901728R.

Espinosa, G.(2013). Nutrition and benign prostatic hyperplasia. Current Opinion in Urology, 23(1), 38-41.

Esser, K. A., Harpole, C..E., Prins, G. S., Diamond, A. M. (2010). Physical Activity Reduces Prostate Carcinogenesis in a Transgenic Model. The Prostate, 9(13), 1372-1377.

Foundation for Korean Urological Association(2019).

Fowke, J. H., Phillips, S., Koyama, T., Byerly, S., Concepcion, R., Motley, S. S. (2013). Association between physical activity, lower urinary tract symptoms (LUTS) and prostate volume. BJU International, 111(1), 122-128.

Gann, P. H., Hennekens, C. H., Ma, J., Longcope, C., \& Stampfer, M. J. (1996). Prospective study of sex hormone levels and risk of prostate cancer. Journal of the National Cancer Institute, 88(16), 1118-1126.

Giovannucci, E. L., Liu, Y., Leitzmann, M. F., Stampfer, M. J., \&
Willett, W. C. (2005). A prospective study of physical activity and incident and fatal prostate cancer. Archives of Internal Medicine, 165(9), 1005-1010.

Hackney, A. C., Sinning, W. E., \& Bruot, B. C. (1988). Reproductive hormonal profiles of endurance trained and untrained males. Medicine and Science in Sports and Exercise, 20(1), 60-65.

Haffner, J., Potiron, E., Bouy,e S., Puech, P., Leroy, X., Lemaitre, L., \& Villers, A. (2009). Peripheral zone prostate cancers: location and intraprostatic patterns of spread at histopathology. Prostate, 69(3), 276-282.

Heikkila, R., Aho, K., Heliovaara, M., Hakama, M., Marniemi, J., Reunanen, A., \& Knekt, P. (1999). Serum testosterone and sex hormone binding globulin concentrations and the risk of prostate carcinoma: A longitudinal study. Cancer, 86(2), 312-315.

Hsing, A. W., Chua, S, Jr, Gao, Y. T., Gentzschein, E., Chang, L., Deng, J., \& Stanczyk, F. Z. (2001). Prostate cancer risk and serum levels of insulin and leptin: A population based study. Journal of the National Cancer Institute, 93(10), 783-789.

Ho, C. K., \& Habib, F. K. (2011). Estrongen and androgen signaling in the pathol-genesis of BPH. Nature Review Urology, 8(1), $29-41$.

Hong, J., Kwon, S., Yoon, H., Lee, H., Lee, B., Kim, H. H., Jeong, E. K., \& Park, H. (2006). Risk factors for benign prostatic hyperplasia in South Korean men. Urologia Internationalis, 76(1), 11-19.

Hong, J., Zhang, G., Dong, F., \& Rechler, M. (2002). Insulin like growth factor (IGF) binding protein 3 mutants that do not bind IGF I or IGF II stimulate apoptosis in human prostate cancer cells. The Journal of Biological Chemistry, 277(12), 10489-10497.

Johnsen, N. F., Tjonneland, A., Thomsen, B. L., Christensen, J., Loft, S., Friedenreich, C., Key, T. J., Allen, N. E., Lahmann, P. H., Mejlvig, L, et al. (2009). Physical activity and risk of prostate cancer in the European Prospective Investigation into Cancer and Nutrition (EPIC) cohort. International Journal of Cancer, 125(4), 902-908.

Kenfield, S. A., Stampfer, M. J., Giovannucci, E., \& Chan, J. M.(2011). Physical activity and survival after prostate cancer diagnosis in the health professionals follow-up study. Journal of Clinical Oncology, 29(6), 726-732.

Ki, Y. K. (2017). Blood physiology and histologic effects of low 
intensity exercise and partial bath of the warmer in the benign prostate hyperplasia experimental model. Graduate School of DongShin University, Doctoral Dissertation.

Kim, C. S. (2007). Benign Prostatic Hyperplasia. Journal of The Korean Medical Association, 50(7), 626-636.

Kim, Y., Sharp, S., Hwang, S, \& Jee, S. H. (2019). Exercise and incidence of myocardial infarction, stroke, hypertension, type 2 diabetes and site-specific cancers: prospective cohort study of 257854 adults in South Korea. BMJ Open, 9(3), e025590. doi: 10.1136. Korean National Cancer Center(2018).

Lagiou, A., Samoli, E., Georgila, C., Minaki, P., Barbouni, A., Tzonou, A., Trichopoulos, D., \& Lagiou, P. (2008). Occupational physical activity in relation with prostate cancer and benign prostatic hyperplasia. European Journal of Cancer Prevention, 17(4), 336-339.

Lee, D. W., Hong, Y. S., Oh, S. H., Lee, Y. H., Ju, J. S. (2019a). The effects of 8-Week endurance training on prostatic autophagy and benign prostatic hyperplasia of rats. Exercise Science, 28(3), 270-279.

Lee, Y. H., Kim, D. H., Yoon, J. H., Ju, J. S. (2019b). Association of exercise with benign prostatic hyperplasia and lower urinary tract symptoms. Exercise Science, 28(1), 3-10.

Lee, H. W., Kim, S. A., Nam, J. W., Kim, M. K., Choi, B. Y., \& Moon, H. S. (2014). The study about physical activity for subjects with prevention of benign prostatic hyperplasia. International Neurourology Journal, 18(3), 155-162.

Leedahl, D. D., Vo, P. D., Maxson, P. M., \& Lovely, J. K. (2013). Benign prostatic hyper-plasia: Implications for pharmacologic treatment and perioperative care. Journal of Pharmacy Practice, 26(1), 52-58.

Li, L., Yu, H., Schumacher, F., Casey, G., \& Witte, J. S. (2003). Relation of serum insulin like growth factor I (IGF I) and IGF binding protein 3 to risk of prostate cancer (United States). Cancer Causes Control, 14(8), 721-726.

Lim, K. B. (2017). Epidemiology of clinical benign prostatic hyperplasia. Asian Journal of Urology, 4(3), 148-151.

Littlejohns, T. J., Travis,b, R. C., Key, T. J., \& Allen, N. E. (2016). Lifestyle factors and prostate-specific antigen (PSA) testing in UK Biobank: Implications for epidemiological research. Cancer Epidemiology, 45, 40-46. doi: 10.1016/j.canep.2016. 09.010 .

Liu, Y., Hu, F., Li, D., Wang, F., Zhu, L., Chen, W., Ge, J., An, R., \& Zhao, Y. (2011). Does physical activity reduce the risk of prostate cancer? A systematic review and meta-analysis European Urology, 60(5), 1029-1044.

Lynch, B. M., Neilson, H. K., \& Friedenreich, C. M. (2011). Physical activity and breast cancer prevention. Recent Results Cancer Research, 186, 13-42. doi: 10.1007/978-3-642-04231$7-2$.

Martin, E. A., Battaglini, C. L., Hands, B., \& Naumann F. (2015). Higher-intensity exercise results in more sustainable improvements for VO2peak for breast and prostate cancer survivors. Oncology Nursing Forum, 42(3), 241-249.

McConnell, J. D. (1991). The pathophysiology of benign prostatic hyperplasia. Journal of Andrology, 12(6), 356-363.

Mishra, S., Scherer, R. W., Snyder, C., Geigle, P. M., Berlanstein, D. R., \& Topaloglu, O. (2012). Exercise interventions on health-related quality of life for people with cancer during active treatment. The Cochrane Database of Systematic Reviews, 15(8), CD008465. doi: 10.1002/14651858.CD008465.

Nickel, J. C. (2008). Inflammation and Benign Prostatic Hyperplasia. The Urologic Clinics of North America, 35(1), 109-115.

Nilsen, T., Romundstad, P. R., \& Vatten, L. J. (2006). Recreational physical activity and risk of prostate cancer: a prospective population-based study in Norway (the HUNT study). International Journal of Cancer, 119(12), 2943-2947.

Ngo, T. H., Barnard, R. J., Tymchuk, C. N., Cohen, P., \& Aronson, W. J. (2002). Effect of diet and exercise on serum insulin, IGF I, and IGFBP 1 levels and growth of LNCaP cells in vitro (United States). Cancer Causes Control, 13(10), 929-935.

Parsons, J. K., Im, R. (2009).. Alcohol consumption is associated with a decreased risk of benign prostatic hyperplasia. The Journal of Urology, 182(4), 1463-1468.

Patel, A. V., Rodriguez, C., Jacobs, E. J., Solomon, L., Thun, M. J., \& Calle, E. E. (2005). Recreational physical activity and risk of prostate cancer in a large cohort of U.S. men. Cancer Eidemiology, Biomarkers \& Prevention, 14(1), 275-279.

Pearson, J.. D., Lei, H.. H., Beaty, T. H., Wiley, K. E., Isaacs, S. D., Isaacs, W. B. (2003). Familial aggregation of bothersome benign prostatic hyperplasia symptoms. Urology, 61(4), 781-785.

Peng, C. C., Liu, J. H., Chang, C. H., Chung, J. Y., Chen, K. C., Chou, K. Y., Peng, R. Y. (2013). Action Mechanism of Ginkgo biloba Leaf Extract Intervened by Exercise Therapy in Treatment of Benign Prostate Hyperplasia. Evidence-based 
Complementary and Alternative Medicine, doi: 10.1155/2013/ 408734.

Pernar, C. H., Ebot, E. M., Wilson, K. M., Mucci, L. A.(2018). The Epidemiology of Prostate Cancer. Cold Spring Harbor Perspectives in Medicine, 8(12), pii: a030361. doi: 10.1101.

Platz, E. A., Kawachi, I., Rimm, E. B., Colditz, G. A, Stampfer, M. J., Willett, W. C., Giovannucci, E. (1998). Physical activity and benign prostatic hyperplasia. Archives of Internal Medicine, 158(21), 2349-2356.

Richman, E. L., Kenfield, S. A., Stampfer, M. J., Paciorek, A., Carroll, P. R., \& Chan, J. M. (2011). Physical activity after diagnosis and risk of prostate cancer progression: Data from the cancer of the prostate strategicurologic research endeavor. Cancer Reserch, 71(11), 3889-3895.

Roehrborn, C. G. (2008). Pathology of benign prostatic hyperplasia. International Journal of Impotence Research, 3, 11-18. doi: 10.1038/ijir.2008.55.

Roehborn, C. G., \& McConneli, J. D. (2007). Benign prostatic hyperplasia: Etiology, pathophysiology, epidemiology, and natural history. In: Kavoussi LR, Novick AC, Partin AW, Peters CA, eds. Campbell-Walsh urology 9th ed. China: Elsevier Inc, 2727-2765.

Saad, F., Sternberg, C. N., Mulders, P. F. A., Niepel, D., \& Tombal, B. F. (2018). The role of bisphosphonates or denosumab in light of the availability of new therapies for prostate cancer. Cancer Treatment Reviews, 68, 25-37. doi: 10.1016/j.ctrv.2018. 04.014 .

Schenk, J. M., Kristal, A. R., Neuhouser, M. L., Tangen, C. M., White, E., Lin, D. W. (2010). Biomarkers of systemic inflammation and risk of incident, symptomatic benign prostatic hyperplasia: results from the prostate cancer prevention trial. American Journal of Epidemiology, 171(5), 571-582.

Scott, J. M., Thomas, S. M., Peppercorn, J. M., Herndon, J. E. 2nd, Douglas, P. S., Khouri, M. G., Dang, C. T., Yu, A. F., Catalina, D., Ciolino, C., Capaci, C., Michalski, M. G., Eves, N. D., \& Jones, L. W. (2020). Effects of Exercise Therapy Dosing
Schedule on Impaired Cardiorespiratory Fitness in Patients With Primary Breast Cancer: A Randomized Controlled Trial. Circulation, 141(7), 560-570.

Stattin, P., Rinaldi, S., Biessy, C., Stenman, U. H., Hallmans, G., \& Kaaks, R. (2004). High levels of circulating insulin like growth factor I increase prostate cancer risk: A prospective study in a population based nonscreened cohort. Journal of Clinical Oncology, 22(15), 3104-3112.

St Sauver, J. L., Jacobson, D. J., Girman, C. J., Lieber, M. M., McGree, M. E., Jacobsen, S. J. (2006). Tracking of longitudinal changes in measures of benign prostatic hyperplasia in a population based cohort. The Journal of Urology, 175(3 Pt 1), 1018-1022.

Sun, J. Y., Shi, L., Gao, X. D., \& Xu, S. F. (2012). Physical activity and risk of lung cancer: a meta-analysis of prospective cohort studies. Asian Pacific Journal of Cancer Prevention, 13(7), 3143-3147.

Travier, N., Velthuis, M. J., Steins Bisschop, C. N., van den Buijs, B., Monninkhof, E. M., \& Backx, F. (2015). Effects of an 18-week exercise programme started early during breast cancer treatment: a randomised controlled trial. BMC Medicine, 13(121). doi: 10.1186/s12916-015-0362-z.

Vesely, S., Knutson, T., Damber, J. E., Dicuio, M., Dahlstrand, C. (2003). Relationship between age, prostate volume, prostatepecific antigen, symptom score and uroflowmetry in men with lower urinary tract symptoms. Scandinavian Journal of Urology and Nephrology, 37(4), 322-328.

Voskuil, D. W., Monninkhof, E. M., Elias, S. G., Vlems, F, A, \& van Leeuwen, F. E. (2007). Physical activity and endometrial cancer risk, a systematic review of current evidence. Cancer Epidemiology Biomarkers Prevention, 16(4), 639-648.

Wolin, K. Y., Grubb, R. L., Pakpahan, R., Ragard, L., Mabie, J., Andriole, G. L., \& Sutcliffe, S. (2015). Physical activity and benign prostatic hyperplasia-related outcomes and nocturia. Medicine \& Science in Sport \& Exercise, 47(3), 581-592.

Wolk, A. (2005). Diet, lifestyle and risk of prostate cancer. Acta Oncologica, 44(3), 277-281. 


\section{전립선암과 양성 전립선 비대증을 위한 운동 치료적 전략}

\section{윤진환}

한남대학교, 스포츠과학과 교수

[목적〕 전립선암과 양성 전립선 비대증 같은 전립선 문제는 안드로겐 및 유전적 요인과 주로 관련된 문제로 인식되어 왔는데, 이러한 문제는 노인들에게 많은 영향을 미쳐 이환율과 사망률에 크게 기여한다. 전립선암과 그와 관련된 치료법은 심혈관 및 성기능 장애와 같은 중요하고 지속적인 이환율을 유발할 수 있는데, 이러한 기능 장애를 예방하거나 완화시키기 위해 다양한 중재가 시도되었다, 본 연구의 목적은 전립선암과 양성 전립 선 비대증을 위한 운동 치료적 전략을 도출하기 위하여 MEDLINE, PubMed와 Scopus 등재된 자료와 이전 의 문헌들을 고찰하였다, (방법) 이 리뷰는 전립선암과 양성 전립선 비대증 환자를 위한 운동의 치료적 전략을 위하여 문헌 고찰하였다. [결과) 전립선암과 양성 전립선 비대증 환자에 있어서 규칙적인 운동과 함께 금연, 적정 체중 유지 등 몇몇 생활습관을 개선하면 공격적인 암의 발병율의 위험을 감소시킬 수 있을 것이다. (결 론] 본 연구의 결과는 신체적 운동 훈련은 전립선 암세포 사멸의 마커를 증가시켜 운동이 전립선암 및 양성 전립선 비대증 치료를 위한 잠재적인 치료 전략으로 제시 될 수 있을 것이다. 미래의 연구들에서는 다양한 전 립선암 및 양성 전립선 비대증 환자에 있어서 적정한 운동 기간, 운동 강도, 운동 빈도를 고려한 연구들이 요구 된다.

주요어: 전립선암, 양성 전립선 비대증, 운동, 전립선 문제 